\title{
Nonsteroidal anti-inflammatory drugs in the treatment of low back pain
}

\section{Louis Kuritzky George P Samraj}

Department of Community Health and Family Medicine, University of Florida, Gainesville, FL, USA
Correspondence: George P Samraj Department of Community Health and Family Medicine, University of Florida, 625 SW 4th Ave, Gainesville, FL 3260I, USA

Tel +I 352392454 I ext 235

Fax + I 3523927766

Email georges@ufl.edu
This article was published in the following Dove Press journal:

Journal of Pain Research

27 November 2012

Number of times this article has been viewed

Abstract: Low back pain (LBP) is amongst the top ten most common conditions presenting to primary care clinicians in the ambulatory setting. Further, it accounts for a significant amount of health care expenditure; indeed, over one third of all disability dollars spent in the United States is attributable to low back pain. In most cases, acute low back pain is a selflimiting disease. There are many evidence-based guidelines for the management of LBP. The most common risk factor for development of LBP is previous LBP, heavy physical work, and psychosocial risk factors. Management of LBP includes identification of red flags, exclusion of specific secondary causes, and comprehensive musculoskeletal/neurological examination of the lower extremities. In uncomplicated LBP, imaging is unnecessary unless symptoms become protracted. Reassurance that LBP will likely resolve and advice to maintain an active lifestyle despite LBP are the cornerstones of management. Medications are provided not because they change the natural history of the disorder, but rather because they enhance the ability of the patient to become more active, and in some cases, to sleep better. The most commonly prescribed medications include nonsteroidal anti-inflammatory drugs (NSAIDs) and muscle relaxants. Although NSAIDs are a chemically diverse class, their similarities, efficacy, tolerability, and adverse effect profile have more similarities than differences. The most common side effects of NSAIDs are gastrointestinal. Agents with cyclo-oxygenase 2 selectivity are associated with reduced gastrointestinal bleeding, but problematic increases in adverse cardiovascular outcomes continue to spark concern. Fortunately, short-term use of NSAIDs for LBP is generally both safe and effective. This review will focus on the role of NSAIDs in the management of LBP.

Keywords: low back pain, non-steroidal anti-inflammatory drugs, cyclo-oxygenase 2

\section{Introduction}

Low back pain (LBP) is amongst the top ten most common reasons for a symptomatic visit to a clinician. ${ }^{1}$ LBP is also responsible for up to one third of all disability dollars spent in the United States. Hence, wise management of LBP is important to restore mobility, reduce pain, and if possible, diminish the likelihood of long-term disability. LBP is not solely a problem in the United States. Indeed, evidence-based clinical guidelines have been issued by many countries. Review of different clinical guidelines for the management of LBP revealed striking similarities in suggested diagnosis and management. ${ }^{2,3}$ Although there are numerous symptomatic treatments for LBP, the purpose of this review is to focus predominantly upon the role of nonsteroidal antiinflammatory drugs (NSAIDs) in the management of LBP. Other treatments will be only discussed in passing. 


\section{Definitions and epidemiology}

According to the European guidelines for management of acute nonspecific back pain in primary care, LBP (also known as lumbosacral pain) is "pain and discomfort, localized below the costal margin and above the inferior gluteal folds, with or without leg pain". ${ }^{4}$ LBP is often categorized by duration of symptoms first, and next by putative etiology. Acute LBP generally lasts less than 6 weeks, subacute LBP lasts 6-12 weeks, and chronic LBP lasts longer than 12 weeks. ${ }^{1}$ Etiologically, "nonspecific LBP" comprises symptoms not attributable to a known condition (eg, infection, tumor, osteoporosis, ankylosing spondylitis, fracture, inflammatory process, radicular syndrome, or cauda equina syndrome). "Recurrent LBP" is defined as a new episode of LBP after a symptom-free period of 6 months, whereas recurrence in less than 6 months is considered as exacerbation of chronic LBP. Within the category of acute LBP, there is sometimes a very brief "hyperacute" period of 24-48 hours during which symptom intensity is so great that sufferers are essentially immobilized, and motion is prevented by pain and intense spasm. Fortunately, this hyperacute LBP is seen in a minority of patients, and generally resolves within 24-48 hours.

The time categorization of LBP is more than academic, in that it is also predictive of prognosis: a high percentage of individuals who progress to chronic LBP will incur longterm disability, with its concomitant economic disadvantages, unemployment, and need for ongoing involvement with the health care system.

LBP is amongst the top ten problems presenting in primary care, whether the population be young adult or senior citizen. ${ }^{1}$ The lifetime prevalence of LBP is $70 \%-90 \%$ in industrialized countries, and the one-year prevalence is $15 \%-45 \%{ }^{5}$ The peak prevalence occurs between the ages of 35 and 55 years. The adult incidence is $5 \%$ per year. ${ }^{4}$ Despite the commonplace presentation of LBP, clinicians may feel some uncertainty regarding optimal symptomatic management.

The natural history of acute LBP indicates that, even in the absence of treatment, up to $70 \%$ of acute LBP cases are resolved within 3 weeks, and up to $90 \%$ by 12 weeks. ${ }^{6-12}$ Unfortunately, $2 \%-7 \%$ of acute LBP cases develop chronic pain, accounting for up to $75 \%-85 \%$ of total worker absenteeism. ${ }^{13}$

The most common risk factors for LBP are previous LBP, heavy physical work (frequent bending, twisting, lifting, pulling, pushing) sedentary lifestyle, workplace vibrations, psychosocial risk factors (stress, distress, anxiety, depression, cognitive functioning, pain behavior), job dissatisfaction, mental stress at work, smoking, obesity, and lack of exercise. ${ }^{4}$ The clinician's task is to exclude the red flags (like age at onset of pain $<20$ or $>55$ years, weight loss, neurologic changes, significant trauma, or chest pain), inform the patient of the generally benign nature of the disorder, encourage physical activity, and reduce pain to enhance mobility, allowing maximum opportunity for return to work as quickly as possible. NSAIDs are one of the pharmacotherapeutic tools which can be used during this process.

\section{Nonsteroidal anti-inflammatory drugs}

It appears that NSAIDs have been used to manage musculoskeletal symptoms since antiquity. Although sodium salicylate (a derivative of various plants, such as willow bark), was probably the first NSAID, gastrointestinal side effects precluded its widespread use. Subsequently, the creation of aspirin in 1897 by means of adding acetic acid to sodium salicylate (invented by chemist Felix Hoffman of the German Friedrich Bayer and Company) allowed for a more tolerable NSAID. ${ }^{14}$

Most patients presenting to the clinician with LBP will have two primary agendas, ie, ascertaining whether important secondary pathology is present (eg, neoplasia, infection, abdominal aortic aneurysm), and relief of pain. ${ }^{15}$ The main clinical goals in the management of acute LBP is to reduce pain, improve mobility, and physical function. NSAIDs are often considered front-line agents because they act rapidly and are generally well tolerated. Cyclo-oxygenase 2 enzyme (Cox-2) inhibitors have some advantage over the Cox-1 inhibitors in terms of safety. Indeed, the majority of patients are likely to have already tried one or more over-thecounter remedies, which may include NSAIDs. ${ }^{16}$ The primary mechanism of action of NSAIDs is blockade of conversion of arachidonic acid to inflammatory prostaglandins, although an impact upon leukotriene production may also play a role. ${ }^{17}$ Cox-2 is the primary pathway through which arachidonic acid is converted into inflammatory prostaglandins, which can produce pain. Hence, interruption of this pathway, an activity common to all NSAIDs (including aspirin) is believed to be the basis of pain relief. Cox-2 is generally believed to be an "inducible enzyme", ie, in the absence of stimuli such as inflammation, Cox-2 is inactive. Cox-2 is also involved in maintenance of renal glomerular flow. Accordingly, when glomerular flow is dependent upon activity of Cox-2 to induce vasodilation, any agent which blocks Cox-2 may result in reduced glomerular flow, with a subsequent increase in sodium, potassium, and water retention, as well as an increase in blood urea nitrogen and creatinine. 
Endoscopy studies indicate that up to $15 \%-30 \%$ of persons on chronic NSAID treatment demonstrate erosions or ulcers. ${ }^{18}$ Unfortunately, symptoms are not an accurate guide to the presence, absence, or severity of gastrointestinal pathology induced by NSAIDs. Even when serious upper gastrointestinal bleeding occurs, it is asymptomatic in the majority of persons until a bleeding event is evident. Hence, clinicians cannot rely upon reports of gastrointestinal tolerability to inform whether gastrointestinal toxicity from NSAIDs is occurring.

The burden of toxicity from NSAIDs belies what had been the widely held perspective that NSAIDs are "safer" analgesics. Both Cox-1 and Cox-2 inhibitors have adverse drug reactions in both the short term and the long term. Indeed, it has been reported that as many as 107,000 hospitalizations and 16,500 deaths annually in the United States may be attributable to NSAID toxicity. ${ }^{19}$ Through the 1990s it was suggested that for every dollar spent on NSAIDs, treatment of NSAID toxicity cost $\$ 1.25 .{ }^{20}$ Similarly, in the United Kingdom, 10,000 hospital admissions and 2000 deaths annually have been attributed to NSAIDs. ${ }^{21}$ Cox-1 appears to be critical in the maintenance of gastrointestinal mucosal integrity. The promise of Cox-2 selective inhibitors was based upon the belief that because the therapeutic effects (analgesic and anti-inflammatory) of NSAIDs reside in Cox-2 inhibition, and most of the toxic effects are a result of Cox-1 inhibition, agents which only impact Cox- 2 might be free of meaningful adverse gastrointestinal effects.

This understanding, although fundamentally sound, turned out to be only partially correct. First, all cyclo-oxygenase selectivity is relative. That is, Cox-2 selective agents have a high relative degree of blockade of Cox-2, while they incur small (but not zero) Cox-1 effects. Additionally, Cox selectivity may be a dose-related phenomenon, and may also vary depending upon the assay used to assess Cox activity. For instance, in the United States, etodolac (Lodine $\left.{ }^{\circledR}\right)$ and meloxicam $\left(\right.$ Mobic $\left.^{\circledR}\right)$ are considered "traditional" (ie, not Cox-2 specific) NSAIDs. In Canada and much of Europe, meloxicam (in particular) was considered a Cox-2 selective agent, based upon the William Harvey human modified whole blood assay. ${ }^{22}$ In keeping with the above, analysis of various NSAIDs by this method at the time indicated that, at $80 \%$ inhibition of Cox-2, rofecoxib, etodolac, and meloxicam were the three most selective NSAIDs tested (all were more Cox-2 selective than the currently available agent, celecoxib). However, even with the most selective agents, some degree of Cox-1 inhibition occurs. ${ }^{16}$ Finally, populations who tend to use NSAIDs commonly or chronically are often of advanced years, and subsequently are also using aspirin long term for the primary or secondary prevention of cardiovascular disease. It has been shown that concomitant administration of aspirin with NSAIDs elevates the risk of gastrointestinal bleeding by $3-4$-fold.

\section{What is the benefit of NSAIDs in LBP?}

According to a Cochrane collaboration review, up to 65 randomized, double-blind, controlled trials $(\mathrm{n}=11,237)$ of NSAIDs for LBP without sciatica were published through 2007. The overarching conclusion demonstrable from these trials was that NSAIDs provide statistically significant symptomatic improvement. These conclusions are only in reference to persons with LBP without sciatica; indeed the Cochrane analysis indicates that LBP with sciatica is not favorably impacted by NSAIDs. ${ }^{23}$ For acute LBP, there are some clinical data suggesting relatively comparable shortterm efficacy of NSAIDs and acetaminophen (paracetamol) in acute LBP. Because this data set is more scanty, and because of increasing recognition of the potential for acetaminophen to have its own meaningful toxicity pattern, NSAIDs still appear preferable to acetaminophen. For patients who achieve adequate symptomatic relief of acute LBP with acetaminophen, as long as dosing limitations are not exceeded, it is a reasonable alternative to NSAIDs.

\section{Is there any difference between the NSAIDs available?}

NSAIDs are competitive, reversible, active site inhibitors of cyclo-oxygenase and are chemically heterogeneous compounds. Cyclo-oxygenase blockade results in inhibition of prostaglandin production. Aspirin and acetaminophen are sometimes conventionally separated from this group due to certain special properties (aspirin acetylates isozymes and inhibits them irreversibly whereas acetaminophen is mainly used as antipyretic, with minimal, if any, anti-inflammatory activity). Chemically, NSAIDs are derivatives of various compounds. See Table 1 for a brief classification of NSAIDs with some examples (note that not all examples mentioned are currently available in the United States).

All currently available NSAIDs work by similar mechanisms, so it is not surprising to find that efficacy amongst them is also quite similar. ${ }^{9}$ Differences in half-life, Cox-2 selectivity, and a few other parameters suggest only modest ability for meaningful discrimination between them. The British National Institute of Clinical Excellence guidelines indicate that "traditional" NSAIDs and Cox-2-selective 
Table I Classification of nonsteroidal anti-inflammatory drugs

\begin{tabular}{ll}
\hline Compounds & Products \\
\hline Salicylates & Aspirin, diflusinal, salsalate \\
Propionic acid derivatives & $\begin{array}{l}\text { lbuprofen, naproxen, fenoprofen, } \\
\text { ketoprofen, flurbiprofen, oxaprozin, } \\
\text { loxoprofen }\end{array}$ \\
Enolic acid (oxicam) & $\begin{array}{l}\text { Piroxicam, meloxicam, tenoxicam, } \\
\text { droxicam, lornoxicam, isoxicam, }\end{array}$ \\
derivatives & phenylbutazone \\
Fenamic acid derivatives & Mefenamic acid, meclofenamic acid, \\
Alkanones & flufenamic acid, tolfenamic acid \\
Acetic acid derivatives & Nabumetone \\
Diaryl heterocyclic & Indomethacin, sulindac, etodolac, \\
compounds & ketorolac, diclofenac, nabumetone \\
Sulphonanilides & Celecoxib, valdecoxib, rofecoxib, \\
Others & etoricoxib \\
\hline
\end{tabular}

agents are equally efficacious, both for reducing pain and improving functionality, at least for osteoarthritis, which is one of the most common indications. Similar conclusions have been determined in other populations. ${ }^{24}$

Both Cox-1 and Cox-2 NSAIDs reduce pain and inflammation in a dose-dependent and time-dependent fashion. ${ }^{25}$ Because of some important intraindividual variation, subjects may have different therapeutic responses to agents which have no major apparent pharmacokinetic or pharmacodynamic differences. It has been suggested that perhaps $70 \%-80 \%$ of individuals will respond favorably to a particular NSAID, ${ }^{26}$ leaving the door open to consider another agent if the first NSAID therapeutic choice does not produce sufficiently favorable effects. Why patients might respond to one agent and not another remains unclear. Because interruption of Cox-1, which is common to essentially all NSAIDs, results in blockade of essential gastrointestinal tract tissue protection, all NSAIDs are associated with an increased risk of gastrointestinal bleeding. ${ }^{27-31}$ Cox-2 inhibition should not be viewed as an absolute category; isoform selectivity for Cox-2 selection is not an absolute but rather a continuous discrete variable. See Table 2 for some of the characteristics of common NSAIDs.

A Cochrane systematic review of NSAIDs concluded that, as a group, these agents (including those that are Cox-2 specific) are essentially equally effective for treatment of LBP, with Cox-2 agents having superior tolerability. ${ }^{17}$ For toxic events like gastrointestinal bleeding, it is difficult to stratify risks amongst the traditional NSAIDs. Because different trials have found different rates of gastrointestinal events, population differences, and overlapping confidence intervals for the incidence of adverse gastrointestinal events associated with traditional NSAIDs, it is difficult to discern meaningful differences between agents. ${ }^{32}$ Among the nonselective NSAIDs, ketorolac and piroxicam appear to be the agents associated with greatest gastrointestinal risk; the protracted half-life of piroxicam ( $>30$ hours) may explain its propensity for causing gastrointestinal toxicity. Oral ketorolac dosing is limited to a 5-day duration due to its well recognized profile of gastrointestinal and renal toxicity. Although ketorolac has potent analgesic capacity, its adverse effect profile suggests that it is not suitable for management of acute LBP or chronic LBP, although a role in the hyperacute phase of LBP is worthy of consideration, especially in patients for whom opioid analgesia is not the best option.

\section{Individual trials in acute LBP}

NSAIDs provide efficacy in acute LBP that is statistically significant. Outcomes in acute LBP are often divided into either composite endpoints (eg, clinician global assessment, patient global assessment), gradation of pain (eg, degree of pain reduction, time to abolition of pain, time to much reduced pain), or return to work (or full normal physical activity). Older trials include endpoints such as degree of spasm or low back flexibility using measurements such as Schober's test.

Because of intraindividual variation, it is not possible to predict which NSAID will be most effective for any one individual. Indeed, it has been consistently reported that some persons who do not respond to one NSAID will, nonetheless, for unexplained reasons, respond well to another. ${ }^{20}$ Included here are data published by the Cochrane Collaboration reviewing outcomes for NSAIDs in back pain. To summarize these data, NSAIDs have provided a statistically significant reduction in pain from baseline when studied in 3-week trials, result in a significantly greater proportion of persons with global improvement, and a decreased need to utilize additional analgesic medication.

\section{NSAIDs in acute LBP: what is the risk?}

It was not until 1998 that Cox-2-selective NSAIDs (celecoxib, rofecoxib) were introduced to the market, followed shortly afterwards by valdecoxib. Most of the toxicity observed with NSAIDs, including aspirin, was attributed to blockade of Cox-1, and agents free of Cox-1 antagonism, it was hoped, might be free of this risk. The risk of "traditional" NSAIDs was highlighted in a 1999 report indicating that NSAID toxicity had resulted in 16,500 deaths in the US secondary to NSAID-induced gastrointestinal bleeding. ${ }^{13}$ 
This concerning adverse event profile was highlighted by the fact that mortality from acquired immune deficiency syndrome in the same year was essentially equivalent. Following on from such information, the idea that antiinflammatory agents which spared Cox-1 (ie, Cox-2-specific agents) was welcomed by clinicians. Probably a better term than either "Cox-2-specific" or "Cox-1-sparing", both of which have entered common parlance, would have been "Cox-2 selective", indicating that although there was less Cox-1 antagonism that with "traditional" or "nonselective" NSAIDs, the selectivity was not $100 \%$ exclusive. Indeed, determining the degree of selectivity became a somewhat embattled topic, because experts are still not universal in their agreement about which measurement of Cox inhibition should be preferred. This resulted in different countries categorizing NSAIDs differently. For instance, meloxicam is sufficiently Cox-2 selective that in Canada it was categorized as a Cox-2 selective agent based upon the William Harvey human modified whole blood assay of Cox. ${ }^{16}$ An alternative assay, used in the United States, classified meloxicam as a "traditional" (not Cox-2 specific) NSAID.

The overt association between NSAID use and gastrointestinal bleeding has resulted in widespread caution regarding the disorder and measures to enhance gastrointestinal protection in persons requiring long-term NSAID treatment. Less well recognized, at least initially, was that there was a relationship between NSAIDs and cardiovascular risk.

\section{Coxibs versus NSAIDs}

Two major clinical trials form the basis of safety comparisons between the coxibs (Cox-2 selective NSAIDs) and "traditional" NSAIDs, ie, CLASS (Celecoxib Long-term Arthritis Safety Study) and the VIGOR (Vioxx Gastrointestinal Outcomes Research) trial. CLASS $(n=7968)$ compared celecoxib $800 \mathrm{mg}$ /day and ibuprofen or diclofenac. The primary outcome of the trial (bleeds, perforations, obstructions) trended towards an advantage for celecoxib (numerically, but not statistically significant fewer endpoints in the celecoxib group). The VIGOR trial $(\mathrm{n}=8076)$ compared rofecoxib $50 \mathrm{mg} /$ day with naproxen in a rheumatoid arthritis population, and found an increased risk of cardiovascular events in rofecoxib-treated subjects, further evaluation of which ultimately led to its removal from the marketplace. CLASS did not show an increased risk of cardiovascular events in subjects receiving celecoxib versus naproxen, but, in contrast with VIGOR, in which aspirin subjects were excluded, aspirin

Table 2 Common nonsteroidal anti-inflammatory drugs

\begin{tabular}{|c|c|c|c|c|c|}
\hline NSAIDs & $\begin{array}{l}\text { Typical adult dose } \\
\text { (oral unless otherwise notated) }\end{array}$ & $\mathbf{T}_{1 / 2}$ & Cox-I & $\begin{array}{l}\text { Cox-2 } \\
\text { selectivity }\end{array}$ & Comments \\
\hline Aspirin & $\begin{array}{l}40-80 \mathrm{mg} / \text { day* } \\
325-650 \mathrm{mg} 4-6 \text { hourly** } \\
\text { I g 4-6 hourly*** }\end{array}$ & $2-3$ hours & $\begin{array}{l}\text { Permanent platelet } \\
\text { Cox-I inhibition } \\
+\end{array}$ & & \\
\hline Acetaminophen & $10-15 \mathrm{mg} / \mathrm{kg}$ every $4-6$ hours & 2 hours & $\begin{array}{l}\text { Weak nonspecific } \\
\text { inhibitor }\end{array}$ & & \\
\hline Indomethacin & $\begin{array}{l}25 \mathrm{mg} 2-3 \text { times/day; } \\
75-100 \mathrm{mg} \text { at night }\end{array}$ & 2.5 hours & ++ & & $\begin{array}{l}\text { I0-40× more potent than } \\
\text { ASA side effects: headache, } \\
\text { neutropenia, thrombocytopenia }\end{array}$ \\
\hline Ketorolac & $30 \mathrm{mg}$ IV or $60 \mathrm{mg}$ IV & 4-6 hours & ++++ & & $\begin{array}{l}\text { Potent analgesic } \\
\text { Poor anti-inflammatory }\end{array}$ \\
\hline Diclofenac & $\begin{array}{l}50 \mathrm{mg} 3 \text { times/day or } \\
75 \mathrm{mg} \text { twice/day }\end{array}$ & $\mathrm{I}-2$ hours & ++ & $\begin{array}{l}<5 \text {-fold } \\
\text { cox } 2\end{array}$ & Highly potent \\
\hline Mefenamic acid & $\begin{array}{l}500 \mathrm{mg} \text { load, then } \\
250 \mathrm{mg} \text { every } 6 \text { hours }\end{array}$ & $3-4$ hours & ++ & & $\begin{array}{l}\text { Similar efficacy as ASA } \\
\text { Central action }\end{array}$ \\
\hline Ibuprofen & $200-800 \mathrm{mg}$ every $4-6$ hours & $2-4$ hours & ++ & & Similar efficacy as ASA \\
\hline Naproxen & $\begin{array}{l}250 \mathrm{mg} 4 \text { times/day or } \\
500 \mathrm{mg} \text { twice/day }\end{array}$ & 14 hours & ++ & & More potent than ASA \\
\hline Fenoprofen & $\begin{array}{l}200 \mathrm{mg} 4-6 \text { times/day; } \\
300-600 \mathrm{mg} 3-4 \text { times/day }\end{array}$ & 2 hours & + & & \\
\hline Ketoprofen & 50-75 mg 3-4 times/day & 2 hours & +++ & & \\
\hline Piroxicam & 20 mg/day & $45-50$ hours & ++ & $\begin{array}{l}<5 \text {-fold } \\
\text { Cox-2 }\end{array}$ & $\begin{array}{l}\text { Similar efficacy as ASA, } \\
\text { better tolerated }\end{array}$ \\
\hline Meloxicam & $7.5-15 \mathrm{mg} /$ day & I5-20 hours & ++ & Cox-2 selectivity & \\
\hline Celecoxib & $100 \mathrm{mg}$ I-2 times/day & $6-12$ hours & & Highly selective & \\
\hline
\end{tabular}

Notes: *antiplatelet; **pain/fever; ***rheumatic fever.

Abbreviations: ASA, aspirin; IM, intramuscular; IV, intravenous; Cox, cyclo-oxygenase enzyme. 
users were not excluded from CLASS, potentially masking any adverse cardiovascular effects of celecoxib. Celecoxib does not appear to have the same cardiovascular limitations as rofecoxib. Indeed, a nested case-control study of risk for acute myocardial infarction and sudden cardiac death comparing risk associated with celecoxib versus rofecoxib found a statistically significant increased risk for rofecoxib subjects in an adult population from California including 2,302,029 person-years of follow-up. ${ }^{33}$

All persons taking NSAIDs are at risk for gastrointestinal bleeding, but several factors are recognized to increase risk, ie, prior ulcer or history of upper gastrointestinal bleed, increasing age, concomitant use of anticoagulants, concomitant use of corticosteroids, high-dose NSAID use, and multiple NSAIDs (including aspirin). ${ }^{26}$ For instance, the combination of a traditional NSAID with even lowdose aspirin essentially doubles the risk of gastrointestinal toxicity. ${ }^{34}$ Serious adverse effects aside, many persons taking therapeutic doses of NSAIDs experience adverse symptoms, including nausea, dyspepsia, or abdominal pain; such adverse events are found in as many as $15 \%-30 \%$ of chronic NSAID users. ${ }^{13}$

\section{Steps to protect against NSAID- induced gastrointestinal toxicity}

Commonsense tools to reduce NSAID-induced gastrointestinal toxicity include using the lowest dose for the shortest interval needed to achieve goals. Similarly, avoidance of multiple simultaneous NSAIDs (including coadministration with aspirin), and exclusion of high-risk persons (eg, the elderly, a history of gastrointestinal bleeding, or receiving systemic corticosteroids) is appropriate.

Several classes of pharmacotherapy have been used to reduce gastrointestinal toxicity. The finding that histamine-2 (H2) receptor antagonists were highly effective in reducing endoscopic ulcers when compared with placebo suggests some potential benefit, at least over the short term, with such therapy. ${ }^{15}$ However, a recent systematic review of $\mathrm{H} 2$ receptor antagonists (eg, cimetidine and ranitidine) found the data were too scanty for reviewers to draw definitive conclusions. ${ }^{15}$ Because it is well recognized that tachyphylaxis to $\mathrm{H} 2$ receptor antagonists occurs fairly quickly, and because highly effective risk reduction with other classes of pharmacotherapy has been documented (see below), use of $\mathrm{H} 2$ receptor antagonists as a therapeutic tool for NSAIDinduced gastrointestinal toxicity should probably not be a primary consideration. Indeed, a double-blind study of cimetidine versus placebo in 104 patients with rheumatoid arthritis taking NSAIDs showed no evidence of a protective effect. $^{35}$

Proton pump inhibitors are generally considered the drugs of choice for preventing NSAID-induced gastrointestinal toxicity, without a clear delineation of which agent to use amongst the many products available (currently there are at least six individual agents, in various preparations and combinations). Because they are well tolerated, relieve dyspeptic symptoms promptly, and have demonstrated efficacy in reducing major gastrointestinal bleeding in individual trials, most clinicians rely upon this class of agents.

Misoprostol has been shown to reduce serious gastrointestinal bleeding complications significantly in patients using traditional NSAIDs. ${ }^{15}$ In a large, double-blind, placebocontrolled trial $(n=8843)$ in adults (mean age 68 years) with rheumatoid arthritis receiving continuous NSAID treatment, misoprostol four times daily reduced serious upper gastrointestinal complications by $40 \% .{ }^{36}$ Despite the aforementioned high level of demonstrated efficacy, utilization of misoprostol has not been met with widespread endorsement by primary care clinicians, because the product is expensive, is recommended for use four times daily, and often produces adverse gastrointestinal symptomatology.

Cox-2-selective NSAIDs have been compared directly with traditional NSAIDs in reference to symptomatic ulcers and serious gastrointestinal complications; for both of these endpoints, Cox-2-selective agents typically provide an approximately $50 \%$ risk reduction. Reduction of endoscopic ulcers was even greater, with a $75 \%$ risk reduction. ${ }^{15}$

Although the notion, as described in systematic reviews on the topic, that Cox-2 selective agents significantly reduce the risk of gastrointestinal toxicity appears to be essentially a foregone conclusion, some detractors have suggested otherwise. For instance, one of the most widely quoted clinical trials substantiating both the safety and efficacy of NSAIDs is CLASS. ${ }^{37}$ Even though CLASS is widely recognized as the pivotal trial documenting the reduced risk profile of Cox-2 agents versus traditional NSAIDs, the strength of these conclusions has been challenged. For instance, it has been pointed out that CLASS was originally designed to go on for one year (and did so), but that the data reported in 2000 only included data to 6 months, at which point the superiority of celecoxib compared with traditional NSAIDs was confirmed. However, the one-year data, using a pre-planned US Food and Drug Administration definition of ulcer-related complications, did not find an advantage for celecoxib. Indeed, in the latter 6 months of the trial (information which was not included in the original CLASS 
trial, as published), most of the ulcer complications occurred in the celecoxib group. ${ }^{38}$

\section{NSAIDs and renal toxicity}

It is estimated that adverse renal effects induced by NSAIDs are as infrequent as $1 \%-5 \%$. Renal prostaglandins are typically activated in states of hypoperfusion, and have little role in day-to-day renal homeostasis in the absence of pathology. ${ }^{39}$ Although these low-risk frequency numbers are reassuring, the large number of individuals who are prescribed NSAIDs or take over-the-counter NSAIDs provides such a large denominator that renal risk becomes important. The mechanisms by which NSAIDs increase blood pressure are complex, and include salt and water retention, as well as blockade of the prostaglandin-mediated blood pressure-lowering effects of angiotensin-converting enzyme inhibitors. ${ }^{39,40}$ As a class, Cox-2 agents have demonstrated no increased risk for renal endpoints according to a recent large meta-analysis including 116,094 subjects. $^{41}$ An exception to this general finding was that rofecoxib (no longer marketed in the United States) was associated with a 53\% relative risk increase for renal endpoints. Celecoxib, the only remaining pharmacologic entity with Food and Drug Administration labeling as Cox-2-selective in the United States, has not shown an increased risk for renal adverse events. ${ }^{35}$

Despite these reassuring data about currently available agents, clinicians should be aware that membranous nephropathy can occur on an idiosyncratic basis in patients taking any NSAID. A review of membranous nephropathy cases from the Mayo Clinic in Rochester, $\mathrm{MN}$, suggested that as many as $10 \%$ of cases were due to NSAIDs. ${ }^{42}$ Hence, clinicians should consider NSAIDs in their differential diagnosis of proteinuria. Fortunately, most cases of membranous nephropathy are reversible upon drug discontinuation.

The potential for adverse effects on glomerular filtration is present for all NSAIDs and Cox-2-selective agents. In particular, for persons in whom activation of prostaglandins is necessary to maintain effective renal glomerular perfusion, any agent which impedes prostaglandin generation (NSAID or Cox-2 agent) can result in a decline in glomerular filtration rate, with attendant retention of sodium, potassium, and water. ${ }^{43}$ Accordingly, hypernatremia and hyperkalemia are not unanticipated consequences of NSAID/Cox-2 treatment in some patients. Similarly, fluid retention secondary to NSAIDs can range from minimally detectible to frank exacerbation of heart failure. Renal consequences appear to be most problematic in persons with underlying reduced renal perfusion, such as heart failure, dehydration, and advanced age. ${ }^{44}$

\section{NSAIDs and cardiovascular toxicity}

Most cardiovascular risk data in relation to NSAIDs emerges from trials in arthritis. Recently, data from the Adenoma Prevention with Celecoxib study provides another population from which risk assessment may be drawn. ${ }^{45}$ Cosponsored by the National Cancer Institute and Pfizer, this trial followed subjects who were randomized to celecoxib or placebo following polypectomy of an adenomatous polyp. The purpose of this double-blind, placebo-controlled trial was to examine the efficacy of celecoxib in the prevention of further adenomatous colonic polyps.

The Adenoma Prevention with Celecoxib study enrolled 2035 patients who were followed for approximately 3 years. During that time period, the composite endpoint of cardiovascular death, myocardial infarction, stroke, or heart failure occurred in $1 \%$ of placebo recipients, $2.3 \%$ of subjects taking celecoxib $400 \mathrm{mg} /$ day, and $3.4 \%$ of those on celecoxib $800 \mathrm{mg} /$ day. Indeed, this elevation of cardiovascular risk was sufficient to cause the Data and Safety Monitoring Board to discontinue the study drug early. Hence, although rofecoxib is often thought of as the only coxib for which cardiovascular risk is increased, these data suggest that other coxibs may also increase this risk.

The mechanism by which coxibs might increase vascular risk is uncertain. One explanation involves the balance between prostacyclin (which causes vasodilation, opposes platelet aggregation, and is modulated by Cox-2) and thromboxane A2 (which produces platelet aggregation and vasoconstriction and is modulated by Cox-1). Because Cox-2 blockade suppresses vascular production of prostacyclin without reducing levels of platelet-derived thromboxane A2 (as opposed to NSAIDs, which block both), this change in balance is thought to predispose to adverse vascular events. $^{46}$

The primary reason for withdrawal of rofecoxib from the market in the United States and other countries was recognition of its adverse cardiovascular event profile. It may be that all NSAIDs have some association with cardiovascular risk. An observational study from the United Kingdom Q Research database looked at odds ratios for use of NSAIDs and myocardial infarction $(n=9218$ cases of first myocardial infarction and 86,349 case controls). ${ }^{47}$ According to this study, the odds ratio for myocardial infarction was substantially increased with both traditional 
NSAIDs (diclofenac, ibuprofen, naproxen) and Cox2-selective agents.

Part of the cardiovascular toxicity profile of NSAIDs includes elevations in blood pressure. On a mean basis, blood pressure elevation induced by NSAIDs does not appear to be very impressive, with a meta-analysis suggesting that mean arterial pressure is increased by about $5 \mathrm{mmHg} .{ }^{48}$ Nonetheless, such increases are sufficient to destabilize blood pressure control in some patients. Additionally, although the mean change in blood pressure may appear modest, some persons experience large increases in blood pressure. It has been suggested that up to $3 \%$ of individuals treated with NSAIDs or Cox-2-selective agents will experience a clinically significant increase in blood pressure. ${ }^{34}$

\section{NSAIDs in combination therapy}

Despite voluminous experience with acute and chronic LBP, the actual tissue derangement or specific pathologic process that leads to pain which persists for a meaningful time period after an insult remains unclear. A popular pain-spasm-pain theory suggests that an initial pain-evoking event results in spasm, which produces accumulation of inflammatory mediators that induce further spasm, and so on. ${ }^{49}$ If this theory is operant, the utilization of skeletal muscle relaxants (eg, cyclobenzaprine metaxalone, methocarbamol) in combination with NSAIDs would be a sensible choice; muscle relaxants might resolve the "spasm" part of the cycle, and NSAIDs address the "inflammatory mediators" component. ${ }^{50}$ Accordingly, some data sets have found that the combination of NSAID with muscle relaxant provides an outcome which is superior to monotherapy. For instance, in a series of acute LBP patients $(n=219)$ treated with a variety of pharmacologic agents (monotherapy or combination therapies), patient satisfaction was highest in users of a muscle relaxant combined with an NSAID. Further, improvements in pain and reduction in disability were statistically superior to placebo when combination therapy was utilized..$^{51}$

\section{Topical NSAIDs}

Prescription topical NSAIDs have been used for longer in Europe than in the United States. A systematic review of topical NSAIDs focusing upon European trials ( $\mathrm{n} \geq 10,000$ subjects) concluded that topical NSAIDs were both safe and effective; indeed, outcomes were remarkably similar in comparator trials which compared a topical versus an oral NSAID. ${ }^{52}$ Recently, two formulations of prescription topical NSAID have received Food and Drug Administration approval, ie, the Flector $^{\circledR}$ patch (1.3\% diclofenac epolamine) applied every
12 hours and Voltaren ${ }^{\circledR}$ gel (1\% diclofenac) applied every 4 hours. Because systemic levels of such topical agents are much reduced due to transdermal administration (providing less than $10 \%$ of the systemic levels seen with the same dose administered orally), ${ }^{53}$ it appears likely that the safety profile will be very favorable compared with systemic antiinflammatory treatment. Nonetheless, cautions about the association between any formulation of diclofenac and serious liver disease recently put forth by the Food and Drug Administration warrant consideration, even for transdermal products. Additionally, to the authors' knowledge, there are no trials specifically in acute LBP or chronic LBP with topical NSAIDs.

\section{NSAIDs in chronic LBP}

The role of NSAIDs in chronic back pain must be tempered with the competing toxicity profile of increased risk for cardiovascular disease, blood pressure elevation, gastrointestinal toxicity, and diverse but less grave adverse effects. Cox-2-specific agents have been successfully trialed. For example, rofecoxib, in two trials comparing doses of $25 \mathrm{mg}$ or $50 \mathrm{mg}$ once daily with placebo in persons with chronic LBP, showed superior efficacy to placebo in pain reduction, as well as lesser use of rescue medication. ${ }^{54}$ Rofecoxib has been removed from the market due to recognition of increased cardiovascular risks. Celecoxib from the same therapeutic class is widely used and has not shown the same degree or consistency of increased cardiovascular risk.

Table 3 includes data from the Cochrane Collaboration on NSAIDs for chronic LBP. In summary, NSAIDs provide superior pain relief to placebo (up to 12 weeks), and show a trend towards superiority over acetaminophen. No statistically significant difference in pain reduction between Cox-2 selective and traditional NSAIDs was seen.

\section{Optimal use of NSAIDs in LBP}

Based upon the foregoing discussion, it is clear that NSAIDs provide some potential clinical benefit for sufferers of LBP, but also entail some risk. The rationale for utilization of NSAIDs in back pain is both relief of pain and enhanced ability for functional mobilization. The back pain literature has documented that whereas traditional thinking in the past had advocated bed rest and/or immobilization as therapy for back pain, neither, when scrutinized in a double-blind fashion, improves outcomes. Indeed, persons who stay as active as possible appear to have the greatest degree of symptom resolution. ${ }^{55}$ To that end, NSAIDs may be appropriately 
Table 3 Meta-analysis of NSAIDs versus placebo in LBP by the Cochrane Collaboration 20II

\begin{tabular}{|c|c|c|c|c|c|c|}
\hline $\begin{array}{l}\text { Comparison: analysis } \\
\text { NSAIDs versus } \\
\text { placebo*** }\end{array}$ & $\begin{array}{l}\text { Condition } \\
\text { Acute LBP* } \\
\text { Chronic LBP** }\end{array}$ & $\begin{array}{l}\text { Number } \\
\text { of patients } \\
\text { (NSAID) }\end{array}$ & Placebo & $\begin{array}{l}\text { Mean difference IV, } \\
\text { random, } 95 \% \mathrm{Cl}\end{array}$ & $\begin{array}{l}\text { Test for overall } \\
\text { effect: } Z\end{array}$ & \\
\hline $\begin{array}{l}\text { Change in pain intensity from } \\
\text { baseline on } 100 \mathrm{~mm} \text { VAS }\end{array}$ & Acute LBP & 375 & 370 & $-8.39[-12.68,-4.10]$ & $3.84(P=0.00013)$ & $\begin{array}{l}\text { Favors } \\
\text { NSAIDs }\end{array}$ \\
\hline $\begin{array}{l}\text { Proportion of patients } \\
\text { experiencing global } \\
\text { improvement }\end{array}$ & Acute LBP & 476 & 478 & $1.19[1.07,1.33]$ & $3.28(P=0.0010)$ & $\begin{array}{l}\text { Favors } \\
\text { NSAID }\end{array}$ \\
\hline $\begin{array}{l}\text { Proportion of patients } \\
\text { experiencing side effects }\end{array}$ & Acute LBP & $\begin{array}{l}907 \text { (total } \\
\text { events }=150)\end{array}$ & $\begin{array}{l}945 \\
\text { (total } \\
\text { events = I16) }\end{array}$ & $1.35[1.09,1.68]$ & $2.74(P=0.006 \mathrm{I})$ & $\begin{array}{l}\text { Favors } \\
\text { placebo }\end{array}$ \\
\hline Additional analgesic use & Acute LBP & $\begin{array}{l}462 \text { (total } \\
\text { events }=208)\end{array}$ & $\begin{array}{l}436 \\
\text { (total } \\
\text { events = 246) }\end{array}$ & $0.80[0.71,0.91]$ & $3.44(P=0.00058)$ & $\begin{array}{l}\text { Favors } \\
\text { NSAID }\end{array}$ \\
\hline $\begin{array}{l}\text { Change in pain intensity from } \\
\text { baseline on } 100 \mathrm{~mm} \text { VAS } \\
\text { LBP without sciatica }\end{array}$ & Acute LBP & 289 & 288 & $-7.69[-12.08,-3.30]$ & $3.43(P=0.00059)$ & $\begin{array}{l}\text { Favors } \\
\text { NSAIDs }\end{array}$ \\
\hline $\begin{array}{l}\text { Change in pain intensity from } \\
\text { baseline on } 100 \mathrm{~mm} \text { VAS } \\
\text { LBP with sciatica }\end{array}$ & Acute LBP & 291 & 274 & $-0.16[-11.92,11.59]$ & $0.03(P=0.98)$ & $\begin{array}{l}\text { No } \\
\text { significance }\end{array}$ \\
\hline $\begin{array}{l}\text { Change in pain intensity } \\
\text { from baseline on } 100 \mathrm{~mm} \\
\text { VAS (mixed population) }\end{array}$ & Acute LBP & 86 & 82 & $-23.40[-43.67,-3.13]$ & $2.26(P=0.024)$ & $\begin{array}{l}\text { Favors } \\
\text { NSAIDs }\end{array}$ \\
\hline $\begin{array}{l}\text { Change in pain intensity from } \\
\text { baseline on } 100 \mathrm{~mm} \text { VAS }\end{array}$ & Chronic LBP & 512 & 508 & $-12.40[-15.53,-9.2]$ & $7.75(P<0.0000 \mathrm{I})$ & $\begin{array}{l}\text { Favors } \\
\text { NSAID }\end{array}$ \\
\hline $\begin{array}{l}\text { Proportion of patients } \\
\text { experiencing side effects }\end{array}$ & Chronic LBP & $\begin{array}{l}519 \text { (total } \\
\text { events }=242)\end{array}$ & $\begin{array}{l}515 \\
\text { (total } \\
\text { events = 195) }\end{array}$ & $1.24[1.07,1.43]$ & $2.95(P=0.0032)$ & $\begin{array}{l}\text { Favors } \\
\text { placebo }\end{array}$ \\
\hline $\begin{array}{l}\text { NSAIDs versus paracetamol, } \\
\text { pain intensity on various scales }\end{array}$ & Acute LBP & $|5|$ & $\begin{array}{l}\text { I58 } \\
\text { (paracetamol) }\end{array}$ & $-0.21[-0.43,0.02]$ & $\mathrm{I} .80(P=0.07 \mathrm{I})$ & $\begin{array}{l}\text { Favors } \\
\text { NSAIDs }\end{array}$ \\
\hline $\begin{array}{l}\text { NSAIDs versus paracetamol, } \\
\text { proportion of patients } \\
\text { experiencing global } \\
\text { improvement }\end{array}$ & Acute LBP & $\begin{array}{l}65 \text { (total } \\
\text { events }=36 \text { ) }\end{array}$ & $\begin{array}{l}63 \\
\text { (paracetamol) } \\
\text { (total } \\
\text { events }=28 \text { ) }\end{array}$ & $1.23[0.88,1.73]$ & $1.22(P=0.22)$ & $\begin{array}{l}\text { Favors } \\
\text { NSAID }\end{array}$ \\
\hline $\begin{array}{l}\text { NSAIDs versus paracetamol, } \\
\text { proportion of patients } \\
\text { experiencing side effects }\end{array}$ & Acute LBP & $\begin{array}{l}\text { I52 (total } \\
\text { events }=33 \text { ) }\end{array}$ & $\begin{array}{l}\text { I57 } \\
\text { (paracetamol) } \\
\text { (total } \\
\text { events = 19) }\end{array}$ & $1.76[1.12,2.76]$ & $2.45(P=0.014)$ & $\begin{array}{l}\text { Favors } \\
\text { paracetamol }\end{array}$ \\
\hline $\begin{array}{l}\text { NSAIDs selective Cox- } 2 \\
\text { inhibition versus nonselective, } \\
\text { change in pain intensity from } \\
\text { baseline on } 100 \mathrm{~mm} \text { VAS }\end{array}$ & Acute LBP & 383 & 378 & $-1.17[-4.67,2.33]$ & $0.65(P=0.5 \mathrm{I})$ & \\
\hline $\begin{array}{l}\text { NSAIDs selective Cox- } 2 \\
\text { inhibition versus nonselective, } \\
\text { change in pain intensity from } \\
\text { baseline on } 100 \mathrm{~mm} \text { VAS }\end{array}$ & $\begin{array}{l}\text { Chronic low } \\
\text { back pain }\end{array}$ & 222 & 218 & $2.00[-1.92,5.92]$ & $1.00(P=0.32)$ & $\begin{array}{l}\text { Favors Cox-2 } \\
\text { selective }\end{array}$ \\
\hline $\begin{array}{l}\text { NSAIDs selective Cox-2 } \\
\text { inhibition versus nonselective, } \\
\text { proportion of patients } \\
\text { experiencing side effects }\end{array}$ & $\begin{array}{l}\text { Acute low } \\
\text { back pain }\end{array}$ & $\begin{array}{l}216 \text { events = } \\
49 \text { (Cox-2 } \\
\text { selective) }\end{array}$ & $\begin{array}{l}212 \\
\text { events }=56 \\
\text { (non } \\
\text { selective) }\end{array}$ & $0.86[0.62,1.20]$ & $0.89(P=0.37)$ & $\begin{array}{l}\text { Favors Cox-2 } \\
\text { selective }\end{array}$ \\
\hline $\begin{array}{l}\text { NSAIDs selective Cox-2 } \\
\text { inhibition versus nonselective, } \\
\text { proportion of patients } \\
\text { experiencing side effects }\end{array}$ & $\begin{array}{l}\text { Subacute } \\
\text { chronic low } \\
\text { back pain }\end{array}$ & $\begin{array}{l}93 \\
\text { events }=26 \\
\text { (Cox-2 } \\
\text { selective) }\end{array}$ & $\begin{array}{l}98 \text { events }= \\
4 I \\
\text { (nonselective) }\end{array}$ & $0.67[0.45,1.00]$ & $1.97(P=0.049)$ & $\begin{array}{l}\text { Favors Cox-2 } \\
\text { elective }\end{array}$ \\
\hline $\begin{array}{l}\text { NSAIDs selective Cox-2 } \\
\text { inhibition versus nonselective, } \\
\text { proportion of patients } \\
\text { experiencing side effects }\end{array}$ & $\begin{array}{l}\text { Chronic low } \\
\text { back pain }\end{array}$ & $\begin{array}{l}222 \\
\text { events }=79 \\
(\text { Cox-2 } \\
\text { selective) }\end{array}$ & $\begin{array}{l}218 \text { events }= \\
87 \\
\text { (nonselective) }\end{array}$ & $0.89[0.70,1.13]$ & $0.93(P=0.35)$ & $\begin{array}{l}\text { Favors Cox-2 } \\
\text { selective }\end{array}$ \\
\hline
\end{tabular}


Table 3 (Continued)

\begin{tabular}{|c|c|c|c|c|c|c|}
\hline $\begin{array}{l}\text { Comparison: analysis } \\
\text { NSAIDs versus } \\
\text { placebo*** }\end{array}$ & $\begin{array}{l}\text { Condition } \\
\text { Acute LBP* } \\
\text { Chronic LBP** }\end{array}$ & $\begin{array}{l}\text { Number } \\
\text { of patients } \\
\text { (NSAID) }\end{array}$ & Placebo & $\begin{array}{l}\text { Mean difference IV, } \\
\text { random, } 95 \% \mathrm{CI}\end{array}$ & $\begin{array}{l}\text { Test for overall } \\
\text { effect: } Z\end{array}$ & \\
\hline $\begin{array}{l}\text { NSAIDs selective Cox- } 2 \\
\text { inhibition versus nonselective, } \\
\text { proportion of patients } \\
\text { experiencing side effects }\end{array}$ & $\begin{array}{l}\text { Chronic low } \\
\text { back pain }\end{array}$ & $\begin{array}{l}531 \\
\text { events }=154 \\
\text { (Cox-2 } \\
\text { selective) }\end{array}$ & $\begin{array}{l}528 \\
\text { events = } 184 \\
\text { (nonselective) }\end{array}$ & $0.83[0.70,0.99]$ & $2.03(P=0.042)$ & $\begin{array}{l}\text { Favors Cox-2 } \\
\text { selective }\end{array}$ \\
\hline $\begin{array}{l}\text { NSAIDs selective Cox-2 } \\
\text { inhibition versus nonselective, } \\
\text { proportion of patients } \\
\text { experiencing gastrointestinal } \\
\text { side effects }\end{array}$ & $\begin{array}{l}\text { Acute low } \\
\text { back pain }\end{array}$ & $\begin{array}{l}164 \\
\text { events }=17 \\
\text { (Cox-2 } \\
\text { selective) }\end{array}$ & $\begin{array}{l}162 \\
\text { events = } 19 \\
\text { (nonselective) }\end{array}$ & $0.88[0.48,1.64]$ & $0.39(P=0.69)$ & $\begin{array}{l}\text { Favors Cox-2 } \\
\text { selective }\end{array}$ \\
\hline $\begin{array}{l}\text { NSAIDs selective Cox-2 } \\
\text { inhibition versus nonselective, } \\
\text { proportion of patients } \\
\text { experiencing gastrointestinal } \\
\text { side effects }\end{array}$ & $\begin{array}{l}\text { Chronic low } \\
\text { back pain }\end{array}$ & $\begin{array}{l}222 \\
\text { events }=30 \\
\text { (Cox-2 } \\
\text { selective) }\end{array}$ & $\begin{array}{l}218 \\
\text { events }=44 \\
\text { (nonselective) }\end{array}$ & $0.67[0.44,1.02]$ & $1.85(P=0.064)$ & $\begin{array}{l}\text { Favors Cox-2 } \\
\text { selective }\end{array}$ \\
\hline $\begin{array}{l}\text { NSAIDs selective Cox-2 } \\
\text { inhibition versus nonselective, } \\
\text { proportion of patients } \\
\text { experiencing gastrointestinal } \\
\text { side effects. Heterogenicity }\end{array}$ & $\begin{array}{l}\text { Chronic low } \\
\text { back pain }\end{array}$ & $\begin{array}{l}386 \\
\text { events }=47 \\
\text { (Cox-2 } \\
\text { selective) }\end{array}$ & $\begin{array}{l}380 \\
\text { events }=63 \\
\text { (nonselective) }\end{array}$ & $0.73[0.52,1.04]$ & I.74 $(P=0.083)$ & $\begin{array}{l}\text { Favors Cox-2 } \\
\text { selective }\end{array}$ \\
\hline
\end{tabular}

Notes: *Acute LBP follow-up $\leq 3$ weeks for acute LBP; **chronic LBP follow up $\leq 12$ weeks; ***NSAIDs versus placebo or other compounds as described in the table.

Abbreviations: Cox, cyclo-oxygenase; LBP, low back pain; NSAIDs, nonsteroidal anti-inflammatory drugs; VAS, visual analog scale.

utilized to reduce pain while patients return to their most active status.

For acute LBP, traditional NSAIDs do reduce pain, without any clear evidence that one agent is superior to another. Therefore, the choice of agent is dependent upon cost, dosing interval, and individual tolerability issues. NSAIDs may be taken on a fixed regimen or as needed for acute LBP, anticipating that a fixed regimen will not be required for longer than a few days in most circumstances. Maintenance treatment with NSAIDs should always prompt consideration of gastroprotective treatment (with proton pump inhibitors, particularly), and especially in persons known to be at higher risk. Cox-2-selective agents have equal efficacy for symptom control in LBP, but probably have lesser gastrointestinal toxicity, albeit at substantially greater economic cost. For persons at very high risk of gastrointestinal bleeding, even when taking a Cox-2-selective agent for sustained treatment, it may be reasonable to also treat with a proton pump inhibitor.

NSAID treatment should be used for the shortest time at the lowest dose that achieves adequate pain relief. Because the majority of acute LBP cases resolve within 2-3 weeks, only a small fraction of LBP sufferers will require NSAID treatment beyond this point. Any time chronic NSAID treatment is utilized, gastrointestinal protection must be considered, and routine monitoring of blood pressure, fluid balance, electrolytes, and renal function is appropriate, especially in high-risk individuals (eg, those with hypertension, congestive heart failure, and chronic kidney disease, the elderly, and the volume-depleted). Chronic use of NSAIDs has been associated with increased cardiovascular risk, such that clinicians must carefully evaluate the risk-benefit relationship whenever long-term therapy is considered.

Most LBP patients are grateful to have an intervention to reduce the burden of pain and enhance their ability to return to functionality as quickly as possible. Short-term use of NSAIDs is appropriate in most cases of acute LBP. The toxicities of chronic NSAID administration are concerning, hence only a very small number of chronic LBP patients should use NSAIDs on other than an as-needed basis, rather than on a maintenance basis.

\section{Disclosure}

The authors report no conflicts of interest in this work.

\section{References}

1. Blount BW, Hart G, Ehreth JL. Description of the content of army family practice. J Am Board Fam Pract. 1993;6:143-152.

2. Koes BW, van Tulder MW, Ostelo R, Kim Burton A, Waddell G. Clinical guidelines for the management of low back pain in primary care: an international comparison. Spine (Phila Pa 1976). 2001;26(22): 2504-2513. 
3. Koes BW, van Tulder M, Lin CW, Macedo LG, McAuley J, Maher C. An updated overview of clinical guidelines for the management of non-specific low back pain in primary care. Eur Spine J. 2010;19: 2075-2094.

4. Guidelines for the management of acute nonspecific low back pain in primary care. Available from: http://www.backpaineurope.org/web/ files/WG1_Guidelines.pdf. Accessed December 7, 2011.

5. Papageorgiou AC, Croft PR, Ferry S, et al. Estimating the prevalence of low back pain in the general population. Evidence from the South Manchester Back Pain Survey. Spine (Phila Pa 1976). 1995;20: 1889-1894.

6. Rathmell JP. A 50-year-old man with chronic LBP. JAMA. 2008;299: 2066-2077.

7. Grotle M, Brox J, Veierød M, et al. Clinical course and prognostic factors in acute low back pain: patients consulting primary care for the first time. Spine (Phila Pa 1976). 2005;30:976-982.

8. Elders L, Burdorf A. Prevalence, incidence, and recurrence of low back pain in scaffolders during a 3-year follow-up study. Spine (Phila Pa 1976). 2004;29:E101-E106.

9. Elders LAM, Van der Beek AJ, Burdorf A. Return to work after sickness absence due to back disorders: a systematic review on intervention strategies. Int Arch Occup Environ Health. 2000;73:339-348.

10. Tousignant M, Rossignol M, Goulet L, et al. Occupational disability to back pain: application of a theoretical model of work disability using prospective cohorts of manual workers. Am J Ind Med. 2000;37: 410-422.

11. Leboeuf-Yde C. Body weight and low back pain: a systematic literature review of 56 journal articles reporting on 65 epidemiologic studies. Spine (Phila Pa 1976). 2000;25:226-237.

12. Jacobs J, Hammerman-Rozenberg R, Cohen A, et al. Chronic back pain among the elderly: prevalence, associations, and predictors. Spine (Phila Pa 1976). 2006;31:E203-E207.

13. Rubin DI. Epidemiology and risk factors for spine pain. Neurol Clin. 2007;25:353-371.

14. Ansani NT, Starz TW. Effective use of nonsteroidal anti-inflammatory drugs. The Female Patient. 2002;27:22-30.

15. Kuritzky L. Pain in the ambulatory setting: the role of nonsteroidal antiinflammatory drugs. Primary Care Special Edition. 2003;7:9-12.

16. Kuritzky L. A practical approach to low back pain. Your Patient and Fitness. 1995;9:22-25.

17. Amadio P, Cummings DM, Amadio PB. NSAIDs revisited. Postgrad Med. 1997;101:257-271.

18. Huang J, Hunt RH. A clinician's view of strategies for preventing NSAID-induced gastrointestinal ulcers. Inflammopharmacology. 1996:4:17-30.

19. Wolfe MM, Lichtenstein DR, Singh G. Gastrointestinal toxicity of nonsteroidal anti-inflammatory drugs. $N$ Engl J Med. 1999;340 1888-1899.

20. Abramson SB, Weaver AL. Current state of therapy for pain and inflammation. Arthritis Res Ther. 2005;7 Suppl 4:S1-S6.

21. Hooper L, Brown TJ, Elliott RA, Payne K, Roberts C, Symmons D. The effectiveness of fine strategies for the prevention of gastrointestinal toxicity induced by NSAIDs: systematic review. BMJ. 2004; 329:948

22. Warner TD, Giuliano F, Vojnovic I, et al. Nonsteroid drug selectivities for cyclooxygenase-1 rather than cyclooxygenase 2 are associated with human gastrointestinal toxicity: a full in vitro analysis. Proc Natl Acad Sci U S A. 1999;96:7563-7568.

23. Roelofs PD, Deyo RA, Koes BW, Scholten RJ, van Tulder MW. Non-steroidal anti-inflammatory drugs for low back pain. Cochrane Database Syst Rev. 2009;1:1-80.

24. Lister BJ, Poland M, DeLapp RE. Efficacy of nabumetone versus diclofenac, naproxen, ibuprofen, and piroxicam in osteoarthritis and rheumatoid arthritis. Am J Med. 1993;95:2S-9S.

25. Cannon GW, Breedveld FC. Efficacy of cyclooxygenase-2 specific inhibitors. Am J Med. 2001;110:6S-12S.
26. Pollison R. Nonsteroidal anti-inflammatory drugs: practical and theoretical considerations in their selection. Am J Med. 1996;100:31S-36S.

27. Weaver A, Rubin B, Caldwell J, et al. Comparison of the efficacy and safety of oxaprozin and nabumetone in the treatment of patients with osteoarthritis of the knee. Clin Ther. 1995;17:735-745.

28. Caldwell JR, Crain D, Hoffmeister RT, et al. Four-way, multicentre, crossover trial of ibuprofen, fenoprofen calcium, naproxen, and tomeltin sodium in osteoarthritis. Southern Med J. 1983;76:706-711.

29. Husby G, Holme I, Rugstad HE, et al. A double blind multicentre trial of piroxicam and naproxen in osteoarthritis. Clin Rheumatol. 1985;5: 84-91.

30. Brown BIL, Johnson JH, Hearron MS. Double-blind comparison of flurbiprofen and sulindac for the treatment of osteoarthritis. Am J Med. 1986;80 (Suppl 3A):112-117.

31. Kolodny AL. Two double-blind trials of diclofenac sodium with aspirin and with naproxen in the treatment of patients with rheumatoid arthritis. J Rheumatol. 1988;15:1205-1211.

32. Laine L. Gastrointestinal effects of NSAIDs and coxibs. J Pain Symptom Manage. 2003;25:32S-40S.

33. Graham DJ, Campen D, Hui R, et al. Risk of acute myocardial infarction and sudden cardiac death in patients treated with cyclo-oxygenase 2 selective and non-selective non-steroidal anti-inflammatory drugs: nested case-control study. Lancet. 2005;365:475-481.

34. Weaver AL. Current and emerging treatments for mild/moderate acute ambulatory pain. Am J Ther. 2008;15:S12-S16.

35. Roth SH, Bennett RE, Mitchell CS, et al. Cimetidine therapy in NSAID drug gastropathy. Arch Intern Med. 1987;147:1798-1801.

36. Silverstein FE, Graham DY, Senior JR, et al. Misoprostol reduces serious gastrointestinal complications in patients with rheumatoid arthritis receiving nonsteroidal anti-inflammatory drugs. Ann Intern Med. 1995;123:241-249.

37. Silverstein FE, Faich G, Goldstein JL, et al. Gastrointestinal toxicity with celecoxib vs NSAIDs for osteoarthritis and rheumatoid arthritis: the CLASS study: a randomized controlled trial. Celecoxib Long-term Arthritis Safety Study. JAMA. 2000;284:1247-1255.

38. Juni P, Rutjes AWS, Dieppe PA. Are selective COX2 inhibitors superior to traditional NSAIDs? Adequate analysis of the CLASS trial indicates that this may not be the case. BMJ. 2002;324:1287-1288.

39. DeMaria AN, Weir MR. Coxibs - beyond the GI tract: renal and cardiovascular issues. J Pain Symptom Manage. 2003;25:S41-S49.

40. Perazella MA. COX-2 inhibitors and the kidney. Hosp Pract (Minneap). 2001;36:43-46.

41. Zhang J, Ding EL, Song Y. Adverse effects of cyclooxygenase 2 inhibitors on renal and arrhythmia events. JAMA. 2006;296:1619-1632.

42. Radford MG, Holley KE, Grande JP, et al. Reversible membranous nephropathy associated with the use of NSAIDs. JAMA. 1996;276: 466-469.

43. Clive DM, Stoff JS. Renal syndromes associated with NSAIDs. $N$ Engl J Med. 1984;310:563-572.

44. Whelton A. Renal aspects of treatment with conventional NSAIDs versus cyclooxygenase-2-specific inhibitors. Am J Med. 2001; 110(Suppl 3A):33S-42S.

45. Solomon SD, McMurray JJV, Pfefer MA, et al. Cardiovascular risk associated with celecoxib in a clinical trial for colorectal adenoma prevention. $N$ Engl J Med. 2005;352:1071-1080.

46. FitzGerald GA. Coxibs and cardiovascular disease. N Engl J Med. 2004; 351:1709-1711.

47. Hippisley-Cox J, Coupland C. Risk of MI in patient taking COX2 inhibitors or conventional NSAIDs: population based nested case-control analysis. BMJ. 2005;330:1366-1369.

48. Zhao SZ, Burke TA, Whelton A, von Allmen H, Henderson SC. Blood pressure destabilization and related healthcare utilization among hypertensive patients using nonspecific NSAIDs and COX2 specific inhibitors. Am J Manag Care. 2002;8:S401-S414.

49. McCarberg BH, Kuritzky L. Low back pain: Identification and management. J Musculoskelet Med. 2003;Supp1:S3-S21. 
50. Cailliet R. Pain: mechanisms, assessment, and management. In: Soft Tissue Pain and Disability. 3rd ed. Philadelphia, PA: FA Davis Co; 1996.

51. Borenstein DG, Lacks S, Wiesel SW. Cyclobenzaprine and naproxen versus naproxen alone in the treatment of acute low back pain and muscle spasm. Clin Ther. 1990;12:125-131.

52. Moore RA, Tramer MR, Carroll D, et al. Quantitative systematic review of topically applied NSAIDs. BMJ. 1998;316:333-338.
53. Heyneman CA, Lawless-Liday C, Walll GC. Oral versus topical NSAIDs in rheumatic disease: a comparison. Drugs. 2000;60:555-574.

54. Ruoff G, Lema M. Strategies in pain management: new and potential indications for COX-2 specific inhibitors. J Pain Symptom Manage. 2003;25:S21-S31.

55. Malmivaara A, Hakiinen U, Aro T, et al. The treatment of low back pain. N Engl J Med. 1995;332:351-355.

\section{Publish your work in this journal}

The Journal of Pain Research is an international, peer-reviewed, open access, online journal that welcomes laboratory and clinical findings in the fields of pain research and the prevention and management of pain. Original research, reviews, symposium reports, hypothesis formation and commentaries are all considered for publication.

\section{Dovepress}

The manuscript management system is completely online and includes a very quick and fair peer-review system, which is all easy to use. Visit http://www.dovepress.com/testimonials.php to read real quotes from published authors. 